\title{
Innovative Exploration on the IOT Mode of Public- private Partnership for Local Vocational Education
}

\author{
Lu Huang \\ School of Political and Public Administration \\ University of Electronic Science and Technology of China, \\ Chengdu, China 610000
}

\begin{abstract}
Speeding up the development of modern vocational education is a major strategic decision made by the Central Committee of CPC and the State Council. Due to the great difficulty for the local finance to guarantee the sustainable development of vocational schools, the urgent need for skilled talents' support with the rapid development of local economy and society, the great promotion of the favorable policy, as well as the satisfaction of PPP (Public-Private Partnership) to the practical needs of development, it is necessary to introduce the PPP mode for the construction and development of local vocational education and choose a more fit mode from it. In the IOT (Invest-Operate-Transfer) mode of PPP, the local public sectors provide the built infrastructures, finance and other incentive mechanism; the private sectors improve or build the infrastructures of vocational education through fixed investment, complete the school management in term of the agreement, transfer the management rights to the local public sectors after the end of the agreement, and get the investment incomes in some way. The IOT mode keeps the public property and non-profit nature of local vocational education unchanged, and solves the problems such as the great pressure of local government expenditure and the development of local vocational education at the same time. It's also important to note that, in the process of introducing IOT mode by the local vocational education, mature laws and regulations, supervision and evaluation for the whole process, perfect contract management, clear division of property rights, comprehensive policy support, as well as effective risk prevention and control should be ensured.
\end{abstract}

Keywords-PPP; the IOT mode; vocational education; local government

\section{INTRODUCTION}

The supply-side reform in the economic field has forced every aspect of the social sphere. Education, as a quasipublic product, is non-exclusive and competitive. According to the attributes and characteristics of education, multiple supply systems can be arranged to balance demand and supply. Since the publishing of The Guidance on the Promotion of Government and Social Capital Cooperation in the Field of Public Services in 2015, the PPP mode has been paid great attention. The public-private partnership, namely PPP, refers to a model in which the public sectors and the private sectors (profit-making organizations, like business organizations or non-profit organizations) establish a partnership [1] and provide public services or products. It

\author{
Xi Yang \\ School of Political and Public Administration \\ University of Electronic Science and Technology of China, \\ Chengdu, China 610000
}

can be divided into 3 categories, including outsourcing, franchising and privatization [2]. A variety of specific cooperation modes are shown in "Table I". Both partners share costs, share benefits and take risks together [3].

TABLE I. The ClASSIFICATION TABLE OF PPP

\begin{tabular}{|c|c|c|c|}
\hline \multirow[t]{16}{*}{ PPP } & \multirow[t]{6}{*}{ Outsourcing } & $\mathrm{SC}$ & Service Outsourcing \\
\hline & & $\mathrm{MC}$ & Management Outsourcing \\
\hline & & DB & Design-Build \\
\hline & & DBMM & Design-Build-Major Maintenance \\
\hline & & DBO & Design-Build-Operation \\
\hline & & $\mathrm{OM}$ & Operation and Maintenance \\
\hline & \multirow[t]{6}{*}{ Franchising } & PUOT & $\begin{array}{l}\text { Purchase-Update-Operation- } \\
\text { Transfer }\end{array}$ \\
\hline & & LUOT & Lease-Update-Operation-Transfer \\
\hline & & BLOT & Build-Lease-Operation-Transfer \\
\hline & & BOOT & Build-Owning-Operation-Transfer \\
\hline & & DBTO & Design-Build-Transfer-Operation \\
\hline & & DBFO & Design-Build-Financing-Operation \\
\hline & \multirow[t]{4}{*}{ Privatization } & PUO & Purchase-Update-Operation \\
\hline & & $\mathrm{BOO}$ & Build-Owning-Operation \\
\hline & & \multicolumn{2}{|c|}{ Stock Right Transfer } \\
\hline & & \multicolumn{2}{|l|}{ Others } \\
\hline
\end{tabular}

II. THE MOTIVATION AND REASONS OF INTRODUCING PPP MODEL INTO LOCAL VOCATIONAL SCHOOLS

\section{A. The Great Difficulty for the Local Finance to Guarantee} the Sustainable Development of Vocational Schools

According to 2011 National Statistics, it is shown that the national education funding is 238,692,936 yuan, of which vocational education funding is $16,385,030$ yuan [4] accounting for only $14.57 \%$. Thus, it can be seen that the scale of funding for vocational education is too small, and the structure of the national educational funding is not reasonable enough. Although the national financial support for vocational education increases every year, the overall growth rate is modest. In addition, the specific national condition of a vast territory and uneven economic development in various regions result in serious financial imbalance in various regions. The local financial support for vocational education is limited, so it is difficult to guarantee the sustainable and rapid development of vocational education. 


\section{B. The Urgent Need for Skilled Talents' Support with the Rapid Development of Local Economy and Society}

At present, the rapid development of economy and society cannot be separated from the support of technical personnel. Because of the unbalanced development of local economy and the severe urbanization in different regions, the gap of the economic and social development between regions is gradually widening. In order to adapt to the current economic and social environment, it is necessary to train qualified personnel with local economic development as the orientation to provide the impetus for the rapid development of local economy and society.

\section{The Vigorous Promotion of Relevant Policies}

The relevant policies of the state have greatly promoted the application and promotion of the PPP mode, and further promoted the application of the PPP mode to local vocational education.

Since 2010, the state has issued numerous policies relating to public-private partnerships, such as: Some Suggestions on Encouraging and Guiding the Healthy Development of Private Investment[5] published by the State Council in 2010, The Franchise Law of infrastructures and Public Utilities[6] which was officially included in the legislative plan in 2013, Decisions Made by the Central Committee of CPC about the Overall Number of Major Issues on All-round Deepening Reform[7] issued by the central authority in 2013, Guidelines on the Government and Social Capital Cooperation[8] issued by the National Development and Reform Commission in 2014, Notice Made by the Ministry of Finance about Related Issues on the Promotion and Using of the Capital Cooperation Mode between Government and Society[9] issued by the Ministry of Finance in 2014, and Guidelines on Promotion of the Capital Cooperation Mode between Government and Society in the Field of Public Service[10] published by General Office of the State Council in 2015. These policy documents, without exception, all believe that promoting the capital cooperation mode between government and society in the field of public service is an important reform measure to transform government functions, stimulate market vitality and create new economic growth points.

More importantly, it is mentioned in The Construction Plan of Modern Vocational Education System (20142020)[11] promulgated in 2014 that it is necessary to accelerate the development of modern vocational education to the construction of the modern vocational education system to help with the achieving the goal of building a moderately prosperous society in all aspects.

\section{The Satisfaction of PPP (Public-Private Partnership) to the Practical Needs of Development}

By attracting investment, local governments make rational use of the advantages of the private capital; give full play to the merits in the aspects like technology, management and supervision under the market mechanism. Besides, through the establishment of public-private partnerships, the construction project can be assessed as early as possible to avoid certain unnecessary risks. It not only solves the problem of insufficient funds, but also makes cost effectiveness obvious. Therefore, it conforms to the needs of the actual development.

\section{INNOVATIVE EXPLORATION ON THE PPP MODE OF LOCAL VOCATIONAL EDUCATION — THE IOT MODE}

\section{A. The Profile of the IOT Mode}

The IOT model (Invest-Operate-transfer) is the innovative use of the DBFO mode and the BOT mode after transformation, which refers to the public sectors' establishment of a long-term partnership agreement with one or more of the private sectors to provide public services or products. The specific process is as follows: the public sectors provide the built infrastructures, finance, other incentive mechanism and so on; the private sectors improve existing infrastructures or build new infrastructures through fixed investment, operate the infrastructures and manage all the business within the agreed period, transfer all infrastructures management rights to the public sectors after the end of the agreement after, and get the investment incomes in some way.

\section{B. Suggestions about Design and Operation of the IOT Mode in Local Vocational Education}

The design of the IOT model in local vocational education is mainly from four aspects, including capital injection from the private sectors to local vocational schools, the absolute rights of management for the private sectors to local vocational schools, sources of interest of the private sectors and recycling of the right of management of vocational schools as shown in "Fig. 1". The IOT model in local vocational education has gone through the process of the private sectors' capital injection to vocational schools, the private sectors' management and operation to vocational schools, and the private sectors' transfer of vocational schools back to the public sectors.

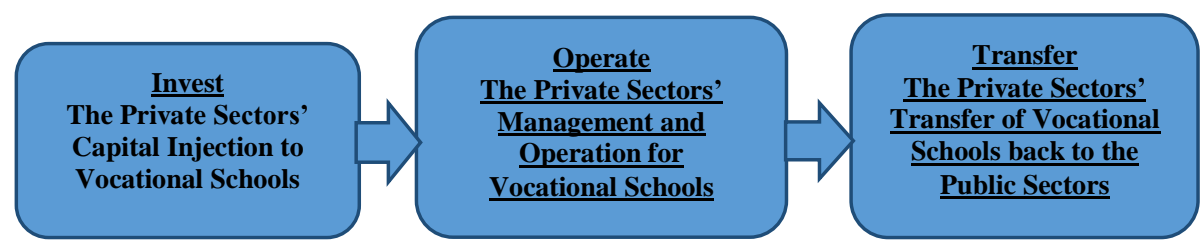

Fig. 1. The flow chart of the iot mode in vocational education. 
1) The private sectors' capital injection to vocational schools: The private sectors exchange capital injection for decades of the right of management of vocational schools, and charge management fees during this period. Therefore, private sectors' capital injection is a prerequisite for the establishment of the IOT model and a necessary condition for private sectors' access to the right of management of vocational schools. The private sectors consult public sectors like governments about the amount of investment according to the specific conditions of different vocational schools.

Furthermore, in actual operation, private sectors can be allowed to inject capital by installments. For example, $50 \%$ of the amount of investment is invested in the first year as the start-up fund, and the remaining $50 \%$ of the amount will be settled in the next few years. Among them, the amount of investment can be divided into the reimbursable amount of investment and the non-refundable amount of investment [13], which is mainly used for the establishment, improvement and upgrading of the hardware and software facilities in vocational schools.

2) The private sectors' management and operation for local vocational schools: After private sectors' capital injection, they can carry out comprehensive rectification and management for the vocational schools to change the inherent and antiquated management system and mechanism of the vocational schools, and introduce advanced management ideas, which will eventually make the vocational schools become the leading schools in local vocational education improvement with development potential and a radiating effect and further create the effect of scale and synergy. The specific contents of the private sectors' right of management are as follows:

a) The rights of management for software and hardware facilities and office supplies of vocational schools: The private sectors have the authority to control, integrate and manage the need and product sources of hardware and software facilities and office supplies of vocational schools, for the private sectors have the authority to manage vocational schools. The private sectors can choose suppliers for themselves within limitation and negotiate quantity and prices for purchasing with suppliers. When the purchase amount reaches a certain amount, the suppliers will definitely provide certain purchase discounts and rebates. Specifically, the suppliers sell hardware, software and other office supplies to the private sectors in accordance with the agreement prices after the private sectors reach a purchase agreement with suppliers, and then the private sectors sell the purchased hardware and software facilities and office supplies to vocational schools in accordance with the bidding price stipulated by the state. The private sectors can earn the difference and rebate between the national bidding price and the agreed price.

b) The management rights of enrollment in vocational schools: The private sectors have absolute rights of management over vocational schools, and the most important thing is the authority of enrollment. Without the violation of the relevant laws and regulations, the private sectors may independently formulate relevant contents such as recruiting majors, recruiting conditions, tuition fees and so on. Try to give the private sectors relatively loose management authority.

c) The management rights of employing: The private sectors work with vocational schools to provide employees. Vocational schools provide teachers and other educational professionals, while the private sectors mainly provide professionals in charge of the aspects such as school management, administrative duties, business procurement, logistics management, and school maintenance. The private sectors can hire employees on its own, have absolute discretion in hiring and can set up salaries for employees by themselves.

3) Private sectors' sources of revenue: The IOT model has significant scale effect due to the huge initial investment and weak increase in later costs. However, it is the public property of vocational education itself that determines the future cash flow must compensate private investment cost, and proper and appropriate income can also help with the improving of the operation efficiency of the IOT mode. The sources of revenue for the private sectors mainly include:

a) Business benefits from hardware and software facilities and office supplies: According to the above introduction to vocational schools' management rights of software and hardware facilities and office supplies, the private sectors can earn the price difference between the national bidding price and the agreed price as well as rebates from the business. Among them, rebates are the amount paid by suppliers to the private sectors, which are about $6 \%-7 \%$ of the purchase price from the private sectors to suppliers.

b) Business incomes from school: The school's business benefits include the amount earned from students' fees, the amount of operating educational brands and selling educational resources. The private sectors, on the basis of complying with relevant laws and regulations, formulate for themselves a series of school costs such as students' tuition fees and accommodation fees. Then the private sectors earn money by the difference between the average income (the government's financial input; the fees charged from students). The private sectors can also sell quality resources such as courseware, video, school-based courses and so on. In addition, the private sectors can make the school an educational base for the renting and utilizing the resources of the school for staff from other schools.

c) Incomes from annual management fees: According to the agreement of the IOT mode of public-private partnership, the private sectors have the right to charge administrative fees from the managed vocational schools. The annual management fees shall be related to the annual income and the amount of the investment repayment of the managed vocational schools. As far as the actual situation is concerned, the private sectors may also receive a certain 
bonus on the basis of the management fees. The payment time of management fees and bonus can be negotiated by the public and private sectors, in which management fees can be settled at the end of a year and bonuses can be settled quarterly. The annual management fees charged by the private sectors shall not exceed the balance of payments of the managed vocational schools. If the managed vocational schools are in a state of deficit in the year, the annual management fees can be used, and even the subsequent annual management fees can be used to pay for the losses of the year so that the managed vocational schools can keep balance of payments.

4) Recovery of vocational schools' management rights: After the expiration of the private sectors' the management time, both parties may terminate the public-private partnership agreement in the IOT mode, or may renew the option. If the choice of termination of the agreement is made, then the government and other public departments will recover all the management rights of schools, but the attributes of public products of vocational schools will keep unchanged.

\section{THE COUNTERMEASURES AND SUGGESTIONS FOR THE SCIENTIFIC APPLICATION OF IOT MODE IN LOCAL VOCATIONAL EDUCATION}

In the process of local vocational education's applying the IOT mode of public-private partnership, it is necessary to have relevant supporting measures as a guarantee to ensure the scientific and rational operation of the IOT mode of PPP.

\section{A. Mature Laws and Regulations}

The practice of the IOT mode of PPP in vocational education must depend on the government's support and the guarantee of laws and regulations. First of all, the government does the top-level design, formulates laws and regulations conducive to the promotion practice of the IOT mode, and build nomocracy environment and nomocracy mechanism, so that it can play a great advantage of publicprivate partnership in accordance with the provisions. To get access according to law, operate according to law and get profits in accordance with the law, and improve operational efficiency and get the maximum benefits on the legal track.

\section{B. Supervision and Evaluation for the Whole Process}

The public sectors, such as the government, need to shift its role in the practice of public-private partnership and supervise the whole operation of the IOT mode. Before the implementation of the IOT project, the private sectors need to participate in bidding. The government and other public departments make prospective assessment to the publicprivate projects submitted by the private sectors; besides, in the implementation of the project, the public sectors need to audit financial supervision of the vocational schools and make sure the legitimacy of the schools' operation; after the implementation of the project, they still need to set up a special evaluation group to evaluate the results of the IOT project.

\section{Perfect Contract Management}

To introduce the IOT of PPP to local vocational education involves many stakeholders, including the vocational schools, the government, private sectors, banks, suppliers and so on. The relationship between them always exists in the whole process of the operation of the project. In order to protect the interests of all parties, it is necessary to formulate a thorough and perfect contract to regulate the obligations and responsibilities of the various stakeholders. In particular, the private sectors must sign agreements with governments and vocational schools, specify the proportion of their allocation, and clearly list the scope and duration of the management of the private sectors, as well as the standard of termination [14]. The private sectors, during the period of operation and management, should sign formal contracts with the third parties like banks and suppliers as an independent legal entity.

\section{Clear Division of Property Rights}

As China's economic system is based on public ownership, the government is the only investor in the traditional infrastructure construction and operation management. Once the IOT mode of PPP is introduced into vocational education, then the subject of the project is the aggregation of the public and private sectors with dual attributes of public ownership and private ownership. Therefore, when the two sides sign a cooperation agreement, clear ownership must be guaranteed, that is, the vocational schools are owned by the public sectors, and their rights like operating rights, management rights, and the right to use, may be licensed to private sectors according to the specific conditions.

\section{E. Comprehensive Policy Support}

In the IOT mode, the introduction of private sectors' capital injection is a very important link, which requires the government to increase its policy support for social capital. First, the government needs to provide policy support in financing, to adjust the bank's credit system, to provide discounts, guarantees and other measures and to encourage banks to open loans to the IOT mode of PPP. The second is to give preferential policies in land acquisition and taxation to fully arouse the enthusiasm of the private sectors [15]. The third one is to protect the interests of the private sectors, that is, the government cannot damage the interests of the private sectors on the basis of ensuring the quality of public education products. Fourth, the government should establish special funds and professional teams for the IOT project to support and guide the successful implementation of it and achieve good results.

\section{F. Effective Risk Management}

Make all IOT projects open and transparent so as to prevent the risk of the project from being uncontrollable. Additionally, there is a need to make long-term plans for the IOT projects of PPP, improve the rules, regulations, risk early warning, emergency response and so on about the operation the project, and to establish a risk assessment mechanism, which is conducive to the dispatch of funds to 
resolve solvency risk [16]. The third party of credit guarantee mechanism can also join in the project, undertake the pledge and guarantee by the third party of the project, and promise to undertake the risk guarantee of part or the entire investment contract amount to the project investor. The third party who undertakes the risk commitment can either be a private sector with solvency, or a commercial bank, an insurance company, etc.

\section{CONCLUSION}

The IOT mode completes the project of public-private partnership through private sectors' capital injection, private sectors' operations and management, and recovery of management rights. The use of the IOT mode to local vocational education can keep the public property and the non-profit nature of the local vocational education unchanged, at the same time it can solve the problems of pressure about fiscal expenditure of local government, local vocational education development and so on. It is believed that the IOT mode can achieve good results and contribute to the development of vocational education or other industries after the completion of relevant supporting measures.

\section{REFERENCES}

[1] Yu D. J., Chen X. \& Cai M. Q. Research on the PPP Mode of New Rural Cooperative Medical Supply [J]. Journal of Shandong University (PHILOSOPHY AND SOCIAL SCIENCES EDITION), 2013, (06): 71-79.

[2] Zhou Z. G., Zhang X. F. \& Zhang P. Problems and Countermeasures in the Application of PPP Mode under New Normal Conditions [J]. China Soft Science, 2015, (09): 82-95.

[3] Yang F. Q. Exploration and Analysis on the Application the PPP Mode in Public Library [J]. Library Construction, 2016, (04): 78$81+86$.

[4] National Data. National Bureau of Statistics of People's Republic of China [DB/OL]. http://data.stats.gov.cn/easyquery.htm, $\mathrm{cn}=\mathrm{C} 01 \& \mathrm{zb}=\mathrm{A} 0 \mathrm{M} 0 \mathrm{Y} 01 \& \mathrm{sj}=2011$,

[5] People's Government of People's Republic of China. Some Suggestions of the State Council on Encouraging and Guiding the Healthy Development of Private Investment

[6] (Guo Fa 2010 No. 13) issued in 2010 No. 13 [EB/OL]. http://www.gov.cn/zwgk/2010-05/13/content_1605218.htm

[7] National Development and Reform Commission of the People's Republic of China. The Franchise Law of infrastructures and Public Utilities [EB/OL].
[EL// http://www.ndrc.gov.cn/zcfb/zcfbl/201504/t20150427_689396.html

[8] The Central People's Government of the People's Republic of China. Decisions Made by the The Central Committee of CPC about the Overall Number of Major Issues on All-round Deepening Reform [EB/OL]. http://www.gov.cn/jrzg/2013-11/15/content_2528179.htm

[9] National Development and Reform Commission of the People's Republic of China. Guidelines on the Government and Social Capital Cooperation

[10] [EB/OL]. http://www.ndrc.gov.cn/gzdt/201412/t20141204_651014.html

[11] The Ministry of Finance of People's Republic of China.

[12] Notice about Related Issues on the Promotion and Using of the Capital Cooperation Mode between Government and Society [EB/OL].

http://www.mof.gov.cn/pub/jinrongsi/zhengwuxinxi/zhengcefabu/201 409/t20140924_1143760.html notice
[13] The Central People's Government of the People's Republic of China. Guidelines on Promotion of the Capital Cooperation Mode between Government and Society in the Field of Public Service [EB/OL]. http://www.gov.cn/zhengce/content/2015-05/22/content_9797.htm

[14] The Ministry of Education of the People's Republic of China. The Construction Plan of Modern Vocational Education System (20142020)

[EB/OL] http://old.moe.gov.cn/publicfiles/business/htmlfiles/moe/moe_630/20 1406/170737.html

[15] Ren X. New Exploration of the IOT Mode of PPP in Public hospitals of the County [J]. China Health Management, 2016, (04): 247-249.

[16] Gao P. C. PPP Mode: the Background, Problems and Ways of Promotion [J]. Local Finance Research, 2014, (09): 18 